\title{
Unintended Consequences of Premature PSA Utilization
}

\author{
Samuel Aronson* \\ Department of Urology, McGill University, Canada
}

Submission:September 20, 2018; Published: September 25, 2018

*Corresponding author: Samuel Aronson, Assistant Professor, Department of Urology, McGill University, Canada,

Email: samuelaronson@hotmail.com

\section{Commentary}

The premature use of some medical innovations has led to unintended negative consequences. One example of unintended consequences was Prostate Specific Antigen (PSA) screening for prostate cancer. Without a full understanding of PSA normal values there was indiscriminate over use of prostate biopsies. Frequently these biopsies diagnosed nonaggressive prostate cancers which cause no harm. As a result, thousands of men underwent unnecessary treatments.

\section{PSA 20 years Later}

In every Urology practice today, refined use of PSA testing is an important component in assessing for prostate cancer. PSA baseline, PSA Progression, PSA Density and PSA analogs are key in evaluating men at risk of cancer. After prostate cancer treatment PSA is the gold standard monitoring blood test.

\section{PSA Refined}

PSA is a good test for indicating prostate cancer when utilized as part of a patient's prostate cancer risk assessment. (PSA is available, widely used and inexpensive)

a) There is no upper limit of normal value for PSA.

b) Always repeat an unusual PSA. PSAs can vary greatly over time and between laboratories.

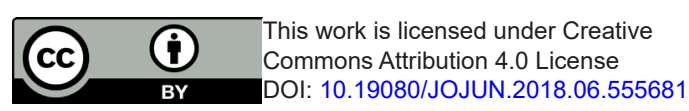

c) Most PSA's reflect benign prostate growth of aging. Cancers cause PSAs to increase higher, faster.

d) Obtain Baseline PSA-men at risk, age 30's (African Am, Family-Genetic History, asymmetric prostate) -- other men age 40 's

e) As prostate cancer indicators PSA alone is OK, PSA progression good and PSA density very good. (PSA Density is PSA divided by prostate volume obtained from prostate ultrasound or MRI)

\section{Prostate MRI}

Men with high risk for prostate cancer benefit from a diagnostic MRI. Prostate MRI decides which men to biopsy, defines the size and location of the suspicious nodule(s) to biopsy, predicts the grade of malignancy and locally stages the cancers. For prostate MRI to be accurate the exam has to be high quality imaging and interpreted by an experienced radiologist. Prostate MRIs are $90 \%$ accurate in diagnosing prostate cancer. Prostate cancers when diagnosed in their early stages with PSA and MRI can be treated and cured.

Your next submission with Juniper Publishers will reach you the below assets

- Quality Editorial service

- Swift Peer Review

- Reprints availability

- E-prints Service

- Manuscript Podcast for convenient understanding

- Global attainment for your research

- Manuscript accessibility in different formats ( Pdf, E-pub, Full Text, Audio)

- Unceasing customer service

Track the below URL for one-step submission https://juniperpublishers.com/online-submission.php 